\title{
Regarding the intersection of metaethics and applied ethics
}

\section{[Na margo prieniku metaetiky a aplikovanej etiky]}

\author{
Marian Ambrozy
}

DOI: 10.18355/XL.2020.13.03.21

\begin{abstract}
Philosophical research devotes little attention to the intersection of metaethics and applied ethics. If researchers devote any attention to these fields, they study them separately. As far as applied ethics of economic nature is concerned, mainly management and business ethics, there are only few researchers studying them in metaethical context. The present paper attempts to map their mutual relations. It asks if it makes sense to connect philosophical and applied ethics. The second question the paper asks is whether it makes sense to connect metaethics and applied ethics. The paper also presents relations between applied ethics and metaethics.
\end{abstract}

Key words: applied ethics, metaethics, management ethics, business ethics, ethical decision-making process, ethical counselling

\begin{abstract}
Abstrakt
Filozofické skúmania venujú malú pozornost' prieniku metaetiky a aplikovanej etiky. Pokial' výskumníci daným oblastiam venujú pozornost', študujú ich samostatne. Pokial' ide o aplikovanú etiku ekonomického charakteru, najmä o manažérsku a obchodnú etiku, existuje len málo výskumníkov, ktorí ich študujú v metaetickom kontexte. Táto práca sa pokúša zmapovat’ ich vzájomné vzt’ahy. Pýta sa, či má zmysel spájat' filozofickú a aplikovanú etiku. Druhá otázka sa pýta, či má zmysel prepojit' metaetiku a aplikovanú etiku. Príspevok tiež predstavuje vzt’ahy medzi aplikovanou etikou a metaetikou.
\end{abstract}

Kl'účové slová: aplikovaná etika, metaetika, manažérska etika, etika podnikania, etický rozhodovací process, etické poradenstvo

\section{Úvod}

V rámci rozčlenenia filozofických subdisciplín patrí výhradné a nezastupitel'né miesto metaetike. Predmetnej etickej disciplíne patrí právom jedno z dominantných miest $\mathrm{v}$ diapazóne rozčlenenia systematickej etiky. Musíme konštatovat', že v rámci slovenskej filozofickej publikačnej scény sa jej nevenuje pozornost', aká jej prináleží z hl'adiska podstaty i štrukturálnej pozície neuralgického bodu etických disciplín. O niečo málo viac rozvinutejšie je skúmanie $\mathrm{v}$ danej oblasti $\mathrm{v}$ českom publikačnom priestore. Oboje konštatovaní platí v oblasti prác, ktoré sa zaoberajú metaetikou. Monograficky jestvuje prehl'adová práca, ktorej autorkou je slovenská etička Ondrejková (Ondrejková, 2000), hlbšou a analyticky viac orientovanou je práca českých autorov Kolára a Svobodu (Kolář - Svoboda, 1997). Čiastočne sa metaetickej problematiky dotýka i monografia Brázdu (Brázda, 2010). Z novších prác možno vyzdvihnút' monografiu od Mahrika (Mahrik, 2018).

Okrem monografických prác vyšlo niekol'ko interesantných časopiseckých filozofických textov k predmetnej problematike. Pozoruhodnými sú texty Mandzelu (Mandzela, 2004) a (Mandzela, 2008). Najmä mladší z jeho článkov možno považovat' za filozoficky inovatívny. Metaetiky sa čiastočne týkajú aj dva wittgensteinovské príspevky teoretičky aplikovanej etiky Remišovej (Remišová, 2003a) a (Remišová, 2003b). Parciálne metaetické prístupy skúmajú aj d’alší autori, 
napr. darwinistickou metaetikou sa zaoberá Hř́ibek (Hribek, 2016), kritikou deskriptivizmu autorka Pacovská (Pacovská, 2006), niečo v zmysle hl’adania vymedzenia miesta pre etiku ako humanitnú disciplínu naznačuje príspevok Navrátilovej (Navratilova, 2006), vymedzenia vzt’ahu etiky a morálky sa dotýka článok Smrekovej (Smrekova, 2004).

Na druhej strane, po páde socializmu pred tridsiatimi rokmi sa otvoril i priestor pre rozvoj etiky ekonomickej proveniencie, alebo lepšie povedané, činnost' na tomto poli vedy dostala zmysel. Otvoril sa v rámci Slovenska a Česka i priestor pre iné videnie filozofie (Dupkala, 2009). Dominancia direktívnych prvkov socialistickej zmiešanej ekonomiky totiž pretrvávala napriek úsiliu (paradoxne) zo strany východných susedov bývalého Československa prehĺbit' proces prestavby hospodárskeho mechanizmu. Napokon až príchod liberálnej zmiešanej ekonomiky s dominantnou zložkou trhovej ekonomiky znamenal diverzifikáciu v potencialite variability správania ekonomických jednotiek. Globálne i lokálne zmeny sa týkajú interakcie prírodných i humanitných vied, ako zdôrazňuje Valčo (Valco, 2018). Nový status quo potreboval teoretickú reflexiu a fundovanie.

Prienik etiky a ekonomiky sa objavil ako nosná téma v prostredí Slovenska pionierskej monografie Lukniča (Luknic, 1994). Nasledovali viaceré monografie Remišovej, z ktorých sa o určité synteticko - holistické uchopenie usiluje najmä práca Etika a ekonomika (Remisova, 2000). Rovnako sú známe viaceré monografie českej proveniencie Zdenka Dytrta - za všetky (Dytrt, 2006), ako aj práca autorov Rolný a Lacina (Rolny - Lacina, 2004). Od vyššie uvedených, ale aj iných autorov sa objavilo niekol'ko vedeckých článkov.

Téma prepojenia aplikovanej etiky $\mathrm{v}$ rôznych ekonomických disciplínach nielen s filozofickou etikou, ale predovšetkým s metaetikou je v rámci českej i slovenskej filozofickej i aplikovanej etiky stále v podstate nedotknutá. Stále jestvuje vol'ný priestor, ktorý je v rámci českej a slovenskej etiky otvorený a čaká na teoretickú reflexiu. Nie je naším zámerom otvárat' neproduktívne prepojenia, súčasný stav poznania umožňuje hl'adanie naozaj rôznych súvislostí v oblasti aplikovanej etiky, ako napr. prienik bioetiky a počítačovej etiky (Hongladarom, 2006: 37). Nejde pritom o nejakú filozofickú reflexiu psychológie, ale o prepojenie manažérskej a podnikatel'skej etiky s metaetikou v snahe o ich hlbšie ukotvenie. Uvedené hl'adanie prepojenia netreba zamieňat' s psychologizáciou etického správania v ekonomickej rovine, čo je posunutie do inej dimenzie problematiky. Na možnosti prepojenia etických a psychologických problémov poukazujú i v našom priestore viacerí fillozofi, napr. Sucharek (Sucharek, 2014). Ide o výsostne humanitnú problematiku. „Vzhl’adom na individuálnu a zároveň sociálnu povahu prostredia, v ktorom človek interaguje, musí byt' štúdium otázky osobnej identity interdisciplinárne“ (Bila, Kacmarova - Vankova, 2015: 430). Problém sa týka aj lingvistického aspektu (Bila, Kacmarova - Vankova, 2016). Nemožno z toho vylúčit' ani teologické disciplíny, napr. biblickú knihu Genezis možno chápat' ako východiskový bod judaistickokrest'anského vnímania l'udskej bytosti (Storoska, 2018: 61). Podl'a Voleka dokonca „biológia spája psychológiu a teológiu na úrovni filozofie“ (Volek, 2015: 1). Zámerne neotvárame tému modalít, hoci ju pokladáme za nesmierne zaujímavú v súvislosti s etickou problematikou, napr. téma vzt’ahu modálneho realizmu a fiktívneho diskurzu, ktorej sa venuje Vacek (Vacek, 2018).

História problematiky je aj v rámci európskej filozofie nesmierne dlhá. Prirodzene, korene má v antickej filozofii. Pokus o teoretické uchopenie základu etiky nemožno ešte nájst' u Empedokla, hoci hovorí o láske a nenávisti, zdanlivo etických fenoménoch, je to úsilie uchopit' filozofickú podstatu fyzis, nie etické skúmanie. Problém otvoril až Platón v dialógiu Politeia. Hoci v diele Sofistes postuluje šesticu, ktorá tvorí kotvoviov $\tau$ ov $\varepsilon 1 \delta o v$, nad ideami dominuje idea Dobra. Táto slovami Platóna osvetluje ostatné idey, pretože im dáva zmysel. Platón myslí na nahliadanie 
podstaty dobra ako ozmyselnenie všetkých etických súdov. Podstatné je, že napriek naznačením štruktúry sveta ideí Platón nikde nepostuluje definíciu dobra. Špekulácie zo strany niektorých odvážnych historikov antickej filozofie, ktorí sa pokúšajú o rekonštrukciu nepísanej náuky nemôžme brat' ako serióznu vedeckú premisu z jednoduchého dôvodu nespol'ahlivosti ich záverov. Podobne, ale už viac konkrétne a menej metaeticky vníma Aristoteles ciel' života človeka vblaženosti. Novoplatonistická metafyzika stavala reálny predikát dobra spolu s jedným nad samotnú existenciu, ako je badatel'né u Plotina a Porfyria.

Myslenie patristiky, východnej i západnej, v celom rozsahu obišlo predmetnú otázku. Patristickým myslitel'om evidentne chýbala motivácia nastolit' ju, ked’že hodnotovo boli úzko kompatibilní krest’anskému metapríbehu, s možnou variabilitou k metapríbehu judaizmu, prípadne manicheizmu. Gnostické myslenie zdanlivo vnášalo chaos, ale zmena úloh v gnostickej soteriológii, prípadne svojská eschatológia neprodukovali priamu potrebu zmeny základu etiky, ktorá bola (bez ohl'adu na jej konkrétne, často diametrálne odlišné etické smernice) plne závislá od kladnej postavy, zväčša predstavujúcej najvyššieho boha. Gnostickému i patristickému mysleniu muselo vystačit', že samotné dobro má metafyzický pôvod v najvyššom bohu, kam treba smerovat' za pomoci (často personálne vel'mi bizarne obsadeného) spasitel'a. Scholastické etické myslenie síce prinieslo nové dimenzie ako zmysel pre intencionalitu u Abelarda, vnímanie úlohy vôle vetike (Duns Scotus) a spojenie cností Platóna a Pavla z Tarzu (Akvinský), avšak metaetickú problematiku rovnako nepotrebovalo otvorit'. Po kvase renesancie a prechodnom oživení novoplatonizmu znamenali určité inovácie vystúpenia etikov Shaftesburryho a Pascala. Fenomén citu v etike bol zjavne nový. Situáciu zneprehl'adnilo vystúpenie pragmatizmu v 19. storočí v USA. Pragmatizmus vníma etiku ako závislú na hodnotách, no zároveň sa objavuje vágnost' uchopenia hodnôt. Hodnotou je v pragmatizme to, čo môže byt' pokladané za užitočné. Dokonca je predmetnému kritériu podriadená i pragmatistická teória pravdy. V Peirceovej abdukcii hrá úlohu dokonca aj inšpirácia aj inštinkt, ako nedávno poukázal Országh (Orszagh, 2019).

Metaetické portfolio sa plne rozvinulo v 20. storočí. Je možné povedat', že z hl'adiska metaetickej problematiky pribudli mnohé nové názorové pozície. Pôdu pripravilo v prvom rade vystúpenie analyticky orientovaných filozofov, započaté Fregem. Hoci sa Frege ketike nevyjadroval, nasledujúca generácia, predovšetkým. Moore a Wittgenstein už priniesli do metaetiky zjavne významné implementy. Predovšetkým šlo o spojenie etiky ako aj celej filozofie s logikou. „Analytická filozofia je tak úzko previazaná s modernou logikou (ako je aristotelovská metafyzika úzko previazaná so sylogistikou) zrejme preto, že vzniklo presvedčenie, že - zjednodušene povedané logika môže byt' pre filozofiu tým, čím bola matematika pre fyziku“ (Zouhar, 2003: 260). Fyzika zohrala v aspekte vzniku analytickej filozofie dôležitú rolu, hoci sa to málokedy pripomína (Zouhar, 2004: 203).

Dnes klasické Wittgensteinove texty charakterizujú etiku ako transcendentálnu. „Je jasné, že etika sa nedá vyslovit'. Etika je transcendentálna“ (Wittgenstein, 1993: 163). V tomto zmysle Wittgenstein dáva v Traktáte etiku a estetiku na jednu platformu. Názory na etiku zostali pevné v ranom i strednom období tvorby. Wittgensteinova známa prednáška o etike, jeden $\mathrm{z}$ dvoch textov, ktoré povolil publikovat', v podstate prinášala až na malé rozdiely rovnaký názor o nevypovedatel'nosti etiky, založenej na neverbalizovatel'nej axiológii, základné uchopenie nevypovedatel'ných hodnôt ako žriedla etiky sa nemení. Ako upozorňuje Remišová, u Wittgensteina v tomto období boli charakteristické predovšetkým tieto názory: „1. Etika sa nedá vyjadrit'. 2. Etika existuje mimo sveta - tak ako dobro, hodnoty, logika. 3. Etika je úzko spojená s mystikou, náboženstvom a metafyzikou. 4. Etika vyrastá z mystiky“ (Remišová, 2003a: 170). Etiku teda vníma ako čosi mimo prírody a vypovedatel'nosti. Malá 
inovácia, ktorú Wittgenstein pridáva vo svojej známej prednáške o etike, je „rozdelenie súdov na relatívne hodnotové súdy a absolútne hodnotové súdy, ktoré v Traktáte chýba“ (Remisova, 2003b: 438). Ako upozorňuje Remišová, na základe článku jeho kolegu a študenta Rheesa je možné pokúsit' sa o rekonštrukciu Wittgensteinových názorov na etiku v 40. rokoch 20 . storočia. V danom pokuse o rekonštrukciu Remišová vníma tieto názory na etiku ako výrazný obrat od raného a stredného obdobia, jeho postoje sa teda menia. Ak máme verit' Rheesovi, podl'a Remišovej došlo k nasledovným zmenám: etiku vníma $\mathrm{v}$ tradičnom zmysle slova, venuje pozornost' konkrétnym bežným morálnym problémom, názory o nevyjadritel'nosti absolútnych súdov spresňuje, etiku vníma ako určité systémy, štrukturalizovane paralelne koexistujúce, do etiky implementuje aj jazykové hry (Remišová, 2003b: 444). Podstatné je, že etiku vníma ako určitú teóriu. Tak, ako sa menia Wittgensteinove názory na náboženstvo, matematiku, na filozofiu všeobecne, tak prichádza nové obdobie jeho názorov na etiku. Kým vo filozofii (všeobecne) a názoroch na náboženstvo možno vnímat' u Wittgensteina tri obdobia, v etike sú to dve obdobia, podobne ako $\mathrm{v}$ matematike. Nota bene, jednotlivé obdobia zmeny názorov na filozofiu všeobecne, matematiku, náboženstvo a etiku sa časovo úplne nezhodujú, nová perióda $\mathrm{v}$ jednom segmente u Wittgensteina automaticky neznamenala zmenu názoru $\mathrm{v}$ inom segmente.

Wittgensteinovo a Moorovo vystúpenie bolo priamou inšpiráciou pre objavenie sa metaetických úvah. Wittgenstein inšpiroval mnohé neskoršie prúdy a osobnosti analytickej filozofie, rovnako logický pozitivizmus ako aj filozofiu prirodzeného jazyka. Moore je pokladaný za samotného zakladatel'a metaetiky, pretovšetkým kvôli monografii Principia Ethica. Leitmotívom monografie je analytický obrat v etike, ktorý spočíval v Moorovom skúmaní hl'adania významu slova dobré. Moore si uvedomuje kardinálny význam predmetného významu rovnako ako Platón. Domnieval sa, že pojem dobro nie je redukovatel'ný na iné pojmy, ani vysvetlitel'ný pomocou nich. Je možné ho definovat' iba ostenzívnou definíciou, pretože ho môžeme pochopit' iba prostredníctvom intuície. Jeho metaetické názory neboli v mnohých rysoch príliš vzdialené od Wittgensteinových pozícií v jeho ranom a prostrednom období tvorby.

Po vypublikovaní Principia Ethica a Wittgensteinovho Traktátu sa otvoril priestor pre postulovanie d’alších metaetických názorových pozícií. Objavilo sa ich viacero a ako je známe, medzi všetkými nie je kompatibilita. Pozoruhodná je pozícia intuicionizmu. Zástancom tejto názorovej pozície je Moore, v podstate ide o historicky najstaršiu metaetickú orientáciu. Intuicionizmus sa objavil i v matematike. Intuicionizmus sa spoliehal na zmysel matematika, prostredníctvom ktorého boli formulované konkrétne matematické hypotézy. Ciel’om je, samozrejme, dokázat' vetu. Typickým predstavitel'om je Poincaré. Zdôrazňoval úlohu heuristiky v matematike. Domnieval sa, že síce potrebujeme logické dôkazy, ale heuristické objavy prichádzajú cez intuíciu. V oblasti geometrie Poincaré veril, že ju nemožno overit', ale overujeme jej primerané spojenie s fyzikou. Podstatné je zvolit' vhodnú geometriu pre predpovede a výpočty. Zatial' čo Poincaré veril, že jednoduchost' euklidovskej geometrie ju predurčuje na úplné použitie vo fyzike, prax ukázala jeho predpoklad ako nesprávny.

Ako sa teda domnieval Moore, dobro je najvyššia etická hodnota, napriek tomu, že nie je definovatel'ná. Obdobným stanoviskom je deontologický intuitivizmus. Spomínaný smer spropagoval najmä Ross. Za d'alších predstavitel'ov možno pokladat' Pricharda a Caritta. Tento pokladá za fundamentálny metaetický pojem, ktorý nemožno redukovat', morálnu povinnost'. Zaujímavost'ou, že základným pojmom tu nie je pojem dobra, ale morálnej povinnosti. Otázkou je, čo sa môže stat', pokial' popri základnej morálnej povinnosti ostane etika stát' aj na určitých hodnotách. Z nášho pohl'adu sa tak človek môže pomerne jednoducho dostat' do vnútornej morálnej kontroverzie. Ide o možný rozpor medzi morálnou povinnost’ou a určitými 
hodnotovými preferenciami, pokial' popri základnej morálnej povinnosti budú etické správanie determinovat' aj hodnoty (ako učebnicový príklad možno uviest' morálnu dilemu v Sofoklovej Elektre). Je dobré poznamenat', že intuicionizmus v etike nie je prítomný iba v metaetike. „Okrem metaetického možno ešte hovorit’ o axiologickom intuicionizme fenomenológie (etické práce N. Hartmanna a M. Schelera, ktorí podobne ako G. E. Moore zdôrazňujú, že hodnotovo orientované výroky, charakteristické pre etiku, nemožno previest' na popisné výroky)“(Ondrejková, 2000: 68).

Historicky má nasledovat' emotivizmus, ktorý sa objavil v súvislosti s logickým pozitivizmom. Hoci zárodky tohto postoja už možno pozorovat' u Huma, v čistej podobe sa objavil v I. polovici 20. storočia. K vzniku dopomohli aj práce Carnapa, ktorý i metafyziku pokladal za emocionálne výpovede. V zmysle rigoróznej pozície tzv. krajný emotivizmus rozpracoval Ayer. Podl'a Ayera sa veda a etika líšia predovšetkým zmyslom a funkciou výpovedí. Kým jazyk vedy opisuje rovinu Sein, tj. ako sa veci majú, jazyk etiky deskribuje rovinu Sollen, tj. ako by to malo byt'. Základnú pozíciu vyjadruje v diele Language, Truth and Logic. Domnieva sa, že spor vedcov je sporom o fakty, no spor etikov sa týka postojov. Inšpirácia Carnapovou kritikou metafyziky je viac než zjavná. Ako pripomína Ondrejková (Ondrejková, 2000) v krajnom emotivizme môže jestvovat' len pluralitná paralelná koexistencia axiologických systémov, ked’že ich možno v podstate všetky považovat' za inkomensurabilné. Obdobný postoj, ale na báze tzv. malých rozprávaní, jazykových hier, zastával neskôr Lyotard. U Ayera je kl'účové vnímat' dištinkciu medzi výrokom a výpoved'ou, upozorn̆uje Ondrejková. Kým výrok nadobúda rôznu pravdivostnú hodnotu, hodnotové otázky môžeme charakterizovat' ako správne a nesprávne v zmysle hodnôt, ktoré pocitujeme. Arzenbacher, Ricken a Fredwel tvrdia, že v podstate ide o skrytú diskusiu o faktoch, podobnú sporu výrokov.

Druhú formu metaetického emotivizmu, umiernený emotivizmus postuloval Stevenson. Ťažiskovou je jeho kniha Ethics and Language (1944). V jeho názorovej pozícii jestvuje zhoda s Ayerom, ale i rozdiel. Rovnako hovorí o rozdielnych funkciách jazyka vedy a jazyka etiky, ale pritom sa domnieva, že etické výpovede nemajú čisto emotívny, ale aj deskriptívny význam. U etických výpovedí je však dôležitejší emotívny význam. Stevenson rozlišuje medzi finálnou a inštrumentálnou hodnotou, tj. medzi konečnou etickou hodnotou a medzi hodnotou v bežnom zmysle slova.

Vývinovo mladším metaetickým smerom je preskriptivizmus. Etikom, ktorý prišiel s touto názorovou pozíciou je Hare. V jeho názoroch je badatel'né ovplyvnenie Austinom. Kým Austin delí výroky na lokúcie, ilokúcie a perlokúcie, Hare určuje tri druhy významov. Rozoznáva deskriptívny význam (opisný), preskriptívny význam (usmerňujúci) a hodnotový význam, ktorý oba predošlé zlučuje. Preskriptívna funkcia jazyka sa dotýka úzko etiky, predovšetkým určuje, čo je žiadúce robit' z etického hl'adiska a čo je naopak pokladané za neželané. Preskripcie môžu pri tom podliehat' hodnotovým súdom. Môžu sa samozrejme vzájomne vylučovat'. Ondrejková (Ondrejkova, 2000: 79) upozorňuje, že niekedy býva naozaj t’ažké upresnit', akej povahy je vlastný súd. Preskripcia tak môže byt' zamenitel'ná s deskripciou, alebo s expresívnou povahou výpovede, jednoznačnost' je sporná, záleží nielen od sémantických, ale aj pragmatických indikátorov. Hare sa zamýšla aj nad možnou kolíziou rôznych morálnych súdov v podobe možných dilem. Tu prináša riešenie, ktoré hovorí o dvoch rovinách etického uvažovania, o kritickej rovine a o intuitívnej rovine. Intuícia nám môže ukazovat' morálny zmysel dvoch kontroverzných etických súdov, ale rovina kriticizmu, kritické myslenie má pomôct' k rozhodnutiu dilemy.

Ďalšou metaetickou pozíciou je teória dobrých dôvodov. Je to v podstate konglomerát teórií, ktoré spája niekol'ko spoločných znakov. Takýmito znakmi je podobná metóda 
hl'adania dôvodov pre etickú argumentáciu. Rôzni teoretici, medzi ktorými možno menovat' Toulmina, Edwardsa, Aikena, Taylora, využívajú na ich hl'adanie viaceré disciplíny ako filozofia, logika, psychológia a pedagogika. Stúpenci tohto stanoviska nesúhlasia so závermi emotivizmu a preskriptivizmu, ked’že argumenty pôsobiace na city alebo usmerňovanie postojov neuznávajú ako relevantné. Tiež sa domnievajú, že pokusy o empirické definovanie základných kategórií etiky, napr. dobra sú a priori neúspešné. Dobro a hodnoty jednoducho pokladajú za plauzibilné, vzhl'adom na heterodoxnost' zloženia l'udskej spoločnosti a rozdielnost' hodnotových systémov.

Metaetický naturalizmus je názorová pozícia, podl'a ktorej je v etike možné poznanie. „V užšom chápaní je termín „,naturalizmus“ chápaný ako označenie pre metaetickú doktrínu, ktorá tvrdí, že mravné súdy nie sú nijako principiálne odlišné od súdov, ktoré popisujú svet z pohl'adu empirických vied“" (Kolar - Svoboda, 1997: 59). Ak máme verit' Platónovým referenciám o Sokratovi, už jeho názorom bolo, že cnosti je možné sa učit. Platón pokladal za fundamentálnu ideu práve ideu Dobra, implicitne teda predpokladal, že náhl'ad na dobro v zmysle hypostazovaného významu slova a teda aj jeho zvrchované poznanie, sú možné. Naturalistickú pozíciu zastávali aj niektorí iní antickí filozofi. Napr. kyrénska škola pokladala za etické pozitívum doslova rozkoš. Výstavba etických príkazov a istého systému u Theodora a Aristippa sa teda odvíjala od princípu rozkoše ako poznatel'nej a najvyššej hodnoty vo svete človeka. Neskorší kognitívny optimizmus možno spájat' s názorom, že je možné vysvetlit' holistické usporiadanie sveta v jednotnom filozofickom obraze. „Filozofická reštitúcia augustínovsko-tomášovskej myšlienky a predstavy univerza ako harmonického a usporiadaného celku, o ktorú sa pokúsil Gottfried Wilhelm Leibniz, spôsobila v konečnom dôsledku jej absolútnu demontáž“ (Abel, 2007: 23). Za d’alšie naturalistické etické pozície možno, pokladat napríklad už spomínanú etiku pragmatizmu, ako aj evolucionistické etiky. Naturalizmus započal obdobie svojej renesancie v USA pred polovicou 20. storočia. Určite nie je povinnost'ou morálneho prírodovedca ponúkat' deduktívne platný argument, ktorého záver obsahuje slovo „mal“", ale žiadny, ktorého premisy obsahujú toto slovo (Joyce, 2006). Za naturalistickú pozíciu možno tiež označit’ antropomorfické poznanie u Florenského. „Ludské poznanie, ktoré má schopnost' byt' životodárnym zdrojom organizmu, ktoré môže byt' základnou oporou či fundamentom osoby, je poznaním symbolickým a to práve preto, lebo skutočné poznanie sveta je vždy antropomorfické“ (Rusnák, 2018: 174).

Za samostatnú názorovú pozíciu metaetiky možno pokladat' aj utilitarizmus. Za jej tradičných predstavitel’ov pokladáme Benthama, Milla, Sidgwicka. Výber žiadúceho správania je podl'a utilitarizmu v tom, že hl'adáme mieru úžitku etického konania. Ako upozorňujú Kolář a Svoboda, možno odlíšit' tzv. utilitarizmus činu (kde sa hodnotí, resp. vyberá konkrétny l'udský čin) a utilitarizmus pravidiel, ktorý považuje za nemožné hodnotit' jednotlivé skutky, ale usiluje sa skúmat' jednanie takého všeobecného spôsobu (matrice) jednania. ktorý sa osvedčil ako užitočný. Je zaujímavé, že k utilitarizmu prejavil sympatiu aj t’ažšie jednoznačne zaraditel'ný americký filozof pracujúci analytickou metódou Smullyan.

Ako sme videli vo viacerých prípadoch, metaetické stanovisko sa niekedy prelína s filozofickým stanoviskom. Obdobne je tomu tak i u Kierkegaarda, mimochodom inšpirujúcu postavu mnohých literárnych diel (Tavilla, 2018). „Otázka, či morálne kategórie patria do sveta relatívnych javov alebo to, či majú svoje vlastné absolútne súradnice, zostáva humanistom nezodpovedaná $\mathrm{z}$ hl’adiska, hoci táto otázka je $\mathrm{v}$ súčasnosti mimoriadne dôležitá a naliehavejšia ako nikdy predtým“ (Mahrik, 2018: 12). Ako upozorn̆uje Mahrik, reálne krest’anstvo Kierkegaard chápe ako transcendentné a nie imanentné náboženstvo. Nesúvisí to s objektívnym popisom Boha, ale s poukázaním, ako človek spoznáva Boha. Kierkegaard počíta pravdu ako niečo mimo sveta a človeka, ktorý sa spolieha spravodlivost' na svete to nemôže 
hl'adat' ani nájst'. Kierkegaard často použiva rôzne pseudonymy, čo st'ažuje niekedy indentifikovat' jeho skutočné pozície. Pokial' je názor človeka iný, než je názor Boha, je omyl stále na strane človeka, domnieva sa. Etické štádium človeka Kierkegaard nadrad'uje nad estetické štádium l'udského života, vníma $\mathrm{v}$ ňom i rozmer pravdy, avšak nechápe ju v zmysle epistemologického významu ktorejkol’vek z teórie právd, ale myslí tým etickú a estetickú dimenziu života, zdôrazňujú Mahrik a kol. (Mahrik Kralik - Tavilla, 2018). Pravdu a pravdivost' Kierkegaard vidí v Kristovi ako v univerzálnom princípe, pretože Kristus ako pravda sa sám realizoval v živote a vo svete ako jednotlivec. Podobné momenty sa objavujú aj voslednom Kierkegaardovom diele Okamžik, mimochodom prvého Kierkegaardovho spisu, preloženého do jazyka, zrozumitel'ného pre Čechov a Slovákov (Cf.: Kralik a Pavlikova, 2013, 82-86; Kralik, 2013: 443-451).

Možno tvrdit', že Kierkegaard bol nepriamym kritikom metaetického naturalizmu v striktnom zmysle slova, ked’že v ňom nevidí relevantné odpovede na zásadné otázky. „Absolútna pravda je dostupná pre každú l'udskú bytost' nie každý akceptuje túto absolútnu pravdu kvôli nedostatku viery“ (Mahrik, 2017: 128). Kierkegaard vníma pravú vieru ako dôveru v živého Boha. Podl’a neho je vnútorným zdrojom existenciálneho pohybu vzt’ah konkrétnej osoby k Bohu ako k pravde. Lásku pritom vníma ako leitmotív celého l’udského snaženia i života človeka vôbec. Osoby ,žijú zo svojho skutočného vzt'ahu s Bohom a na tomto základe kultivujú svoje vlastné vzt'ahy s ostatnými“ (Pavlíková - Žalec, 2019: 1015). Ako podotýka Aguas (Aguas, 2006), táto dimenzia je možná pri rešpektovaní náboženskej slobody, a tá je zasa možná len pri rešpekte k pravdám a hodnotám jednotlivých náboženstiev.

Možno si položit' dve základné otázky. Tú prvú sa môžeme opýtat' spolu s enfant terrible Rortym - je filozofia relevantná pre aplikovanú etiku? Ak položíme otázku, smerovanú na aplikovaného etika, o ktorých etikov sa vo svojej intelektuálnej práci opiera, asi sotva by, ak má elementárnu vedeckú úroveň, odpovedal, že sa opiera o všetkých etikov. Metaetické i filozofické ukotvenie rôznych etických názorových pozícií je v mnohých prípadoch nutne nielen nekompatibilné, ale až kontradiktorické. Má však aplikovaná etika potrebu opierat' sa o filozofickú etiku, a tým vlastne o filozofiu vôbec?

Rorty vníma akmé filozofie v čase pôsobenia Hegela a Humboldta. Od tých dôb podl'a Rortyho, stratila prestíž, postihla ju marginalizácia (Rorty, 2006: 370). Poukazuje na zneužitel'nost' filozofie pre ospravedlňovanie rôznych zločinov rozličných ideológií a organizovaných náboženských spoločenstiev. Podotýka, že filozofia a jej vývoj je vurčitej izolácii od histórie ekonomického myslenia. Domnieva sa, že filozofická etika neprispela k celkovému morálnemu progresu. Premýšl'ajúca osobnost' má $\mathrm{k}$ dispozícii omnoho viac názorov a možností. Východisko vidí Rorty napríklad v pragmatistických postojoch Deweyho, $\mathrm{k}$ (meta)etickému naturalizmu sa stavia skepticky. Neverí, že vedomostné kompetencie vedú človeka $\mathrm{k}$ väčšiemu zmyslu pre morálnu imagináciu (v zmysle aplikovanej etičky Werhane). Spoločenstvo aplikovaných etikov ekonomickej proveniencie podl'a Rortyho nepotrebuje l'udí s vedomost'ami o teóriách morálky, než ich potrebujú pre kvalitný výkon ich práce novinári alebo spisovatelia, uzatvára (Rorty, 2006: 378). Rortyho metaetické názory nevzbudzujú u všetkých filozofov rešpekt ako vnútorne bezproblémové. Donelson pokladá Rortyho metaetiku za neuskutočnitel'nú v jeho vlastnej filozofii, tvrdí, že „Rorty nezodpovedá a nemôže zostat' verný metodickému prístupu k metaetike, ktorý obhajuje“ (Donelson, 2017: 292).

Pragmatisticky orientovaný Rorty teda nevidí opodstatnenie vzt'ahu filozofickej a aplikovanej etiky v zmysle potreby disponovat' kompetenciami filozoficko-etických vedomostí, odpoved' na prvú položenú otázku je z jeho strany negatívna. Môžeme uviest' názor, že aj pragmatistické metaetické presvedčenie môže byt' vedomé 
a založené na vedomostných teoretických kompetenciách pragmatisticky zameraného aplikovaného etika. Napríklad „filozofi s pragmatickým presvedčením urobia vedecké rozhodnutie o tom, ktoré hypotézy prijat' alebo odmietnut', podstatne zahrňujúc etické hodnotenia, ako aj priamu epistémickú evaluáciu koherencie, vecnej podpory atd'.“ (Alexander, 1974: 392).

S prvou otázkou úzko súvisí aj druhá otázka. Je pre aplikovanú etiku relevantná metaetika? Otázka môže zdanlivo pripomínat' problém, ktorý rieši Joaquin: či je logika ontologicky záväznou, či má metafyzické základy (Joaquin, 2013: 87). Pokus o odpoved' môžeme formulovat' na základe rozličných súvislostí. V preskriptivistickej metaetickej pozícii Hare odlišuje dve roviny morálneho myslenia, rovinu kriticizmu a rovinu intuicionizmu. Podstatné je dôjst' k nejakému etickému rozhodnutiu. Kritická, teda rozumová rovina je nadradená rovine intuicionizmu. Hierarchia sa prejaví najmä vtedy, pokial' nastane kolízia morálnych súdov. Ich nekompatibilita znamená nutnost' rozhodnút' sa pre jeden z nich. Preskripcia súvisí s deskripciou, usmerňujúca funkcia je spojená s kritickým myslením. Je potrebné rozhodnút' sa pre jeden z morálnych súdov. V takom prípade je dôležité orientovat' sa predovšetkým v niektorých skupinách indikátorov. Je potrebné podrobne rozpoznat' záujmy, rovnako zistit' afinitu zúčastnených osôb k predmetným záujmom, získat' určité predstavy o postupe v hodnotení a rovnako si uvedomit' predpokladané následky výberu možných rozhodnutí (Ondrejková, 2000: 80).

Načrtli sme teda problém rozhodovania. Etické rozhodovanie v praktickej aplikovanej etike je problémom, ktorý skutočne môže mat' priamu súvislost' s metaetickou pozíciou. Etický problém nebýva v zmysle rozhodovania hlbšie problematický. Tento problém je jednoznačne kategorizovatel'ný, rozhodovanie $\mathrm{v}$ n̆om býva jednoznačné. Rozhodovanie $\mathrm{v}$ etickom probléme je konvergentnou úlohou. V etickom probléme konflikt vyriešime s konečnou platnost'ou (Luknič, 1994). I na to je potrebné opriet' sa bud' o hodnoty, alebo uvažovania, čo znova súvisí s predstavenou metaetickou problematikou. Druhý typ konfliktu „sa nedá vyselektovat' z danej situácie a sú na ňom zúčastnené viaceré subjekty, teda aj jeho riešenie bude mat' dopad na viacerých účastníkov“ (Luknič, 1994: 62). V takom prípade hovoríme o etickej dileme. Priame rozhodovanie etickej dilemy je divergentnou úlohou. Rozhodovanie máva podobu viacerých zúčastnených strán, je viacrozmerným. Indikátory rozhodovania môžu byt' ovplyvnené preskriptivizmom, kde Hare navrhuje rozpoznanie záujmov, zváženie predstáv o postupe pri hodnotení a možné následky rozhodnutia. Rovnako pri rozhodnutí v aplikovanej etike, napr. manažérskej alebo podnikatel'skej etike, sa postupuje identifikáciou problému, nasleduje identifikácia zúčastnených, diagnostifikácia situácie, aplikácia stavu potencialít (minimálne jedna možnost’ a alternatíva). V etickej dileme nejde o zhodu názorov, aj pri najlepšej vôli zachovat' sa správne. Hodnoty a uvažovanie spolu súvisia, ako píše Luknič, ohraničením a dichotomizáciou problému, rovnako usmerňujú posudzovanie. S obhájením hodnôt v rámci potenciálneho rozhodovania a tým aj zodpovednosti, súvisí práve metaetický aspekt. Naše hodnotenia ovplyvňujú emócie, intuícia aj vlastné osobné hodnoty, ako aj kritické myslenie. V oblasti aplikovanej podnikatel'skej alebo manažérskej etiky bývajú tieto dilemy vel’mi zložité (Luknič, 1994: 65). Zároveň ako píše Polačko má svoj vplyv na tieto aspekty rozhodovania aj makroúroveň, ktorú by sme mohli stotožnit' s kultúrnou a civilizačnou podmienenost'ou. (Polacko, 2019). Metaetická rovina uvažovania ako najvyššia má vplyv na normatívnu etiku a tým i na rozhodovanie. Metaetické teoretizovanie môže mat' priamy i nepriamy vplyv na produkciu nástojov aplikovanej etiky alebo priamo pri rozhodovaní v etických dilemách.

Vel'mi podobne uvažuje v modeli etického rozhodnutia Remišová, ktorá sa pýta na okruh poškodených a tých, ktorým sa pomôže, na dobrovol'nost' v situácii, vinníka situácie, možnosti rozhodovania (mapovanie možností), výsledky rôznych riešení, 
rovnako najviac želatel'né výsledky, spolu s nákladmi každej vol’by. Taktiež sa domnieva, že na rozhodovanie majú vplyv indikátory ako hodnoty a stupeň morálneho poznania jednotlivca (Remisova, 2000: 101). Predovšetkým možno nájst' zhodu v oblasti etických dilem, avšak rôzna orientácia jednotlivca môže byt' spôsobená i metaetickým ukotvením jeho etického uvažovania, napr. argumentuje pocitmi, alebo argumentuje racionálne dobrými dôvodmi. Etická dilema zachytáva pri tom dve úrovne, individuálnu aj inštitucionálnu. Metaetické stanovisko môže ovplyvnit' indiciduálnu rovinu primárne a inštitucionálnu rovinu sekundárne, cez tvorcov etických inštitúcií. V oblasti aplikovanej etiky ekonomickej proveniencie sa vyskytuje eticko - ekonomická dilema, ktorej postup riešenia prechádza cez analýzu problému, identifikovanie etickej a ekonomickej stránky problému, výpočet možných riešení, vlastné rozhodnutie a jeho zdôvodnenie (Remisova, 2000: 104). Predmetná schéma riešenia nevykazuje tie podobné znaky s všeobecnou analýzou etickej dilemy, ako ju zachytáva Hare. V modeli etického rozhodnutia podl'a Remišovej je s Hareovým návodom na riešenie spoločného viac, rozpoznanie záujmov a možnost' poškodenia a pomoci pre stakeholderov, taktiež inklinácia $\mathrm{k}$ nim, výsledky riešení a predstavy o valuačnom procese, následky možného riešenia a náklady konkrétnej vol’by. Napokon, i Remišová uvádza, že uvažovanie etickej dimenzie problému podčiarkuje aj Hare, ktorý si myslí, že rozhodnutia sú rozhodnutiami princípov (Remisova, 2000: 104).

Hare sa domnieva, že bytost' vnímajúca metafyzický základ vo svojej totalite a z toho plynúci úplný definitívny systém hodnôt by si vystačila s vlastnou intuíciou, bez akejkol'vek potreby dodatočnej korekcie. Preto intuíciu musíme korigovat' kritickým myslením. Hare hovorí o vlastnom teste kritického myslenia, intuitívne sa rozhodujeme iba prvoplánovo, t. j. ak je rozhodnutie podl'a kritickej analýzy nemožné, respektíve pokial' ide o rutinné rozhodnutie. Kritické uvažovanie v prípade rozhodovania $\mathrm{v}$ zmysle procesu, nie automatickej činnosti nie je jediné, svoje miesto má aj intuitívna zložka. Príkladov na rozhodovanie skrz kritické uvažovanie je mnoho, môžeme uviest' rozpočtovú kalkuláciu a chut'ovú kvalitu pri rozhodovaní študentov univerzít pri stravovaní (Delayco, Biana, 2015), alebo problematiku či a do akej miery možno zapájat’ deti do biznisu (Mabaquiao, 2012).

$\mathrm{S}$ pertraktovanou problematikou súvisí názor Aikena, že jestvujú aspoň tri etické postuláty, ktoré sú $\mathrm{v}$ rámci metaetickej teórie dobrých dôvodov považovatel'né za rovnako hodnotné, pričom nie je možné vybrat' jeden z nich na úkor druhého. Za také pokladá požiadavku nebyt' príčinou utrpenia, statočnost' v etickom jednaní s l'ud'mi, ktorú vníma ako spravodlivost' a stráženie možností slobodného rozhodnutia pre subjekty.

Kontraproduktívne môžu pôsobit' náhl'ady niektorých metaetikov na povahu etických súdov. Kým preskriptivizmus pripúšt’a kombináciu deskriptívnych a preskriptívnych súdov, niektorí metaetici hovoria o priepasti medzi takými súdmi, ktorú pokladajú za neprekonatel'nú. Putnam hovorí, že ide v podstate o rovnaký druh dichotómie, ako je rozdiel medzi analytickými a syntetickými súdmi. „Zástancovia tejto tézy o nepreklenutel'nej priepasti medzi faktuálnymi (deskriptívnymi) a hodnotovými (preskriptívnymi) súdmi považujú za logickú chybu (the is-ought fallacy) každú snahu o preklenutie tejto priepasti. Každá etická koncepcia s kognitívnym nárokom sa potom javí ako následok nejakej konkrétnej logickej chyby“ (Mandzela, 2008: 704). Takéto metaetické závery dávajú etikom príčinu v niektorých prípadoch ignorovat' metaetické skúmania. „Mnohé závery vyplývajúce z metaetických teórií majú pre etiku závažné dôsledky. Tieto teórie tak budia dojem, že etici majú v dnešnej dobe perspektívy, ktoré sú pre etiku sotva prijatel'né“ (Mandzela, 2004: 654). Niektorí autori sa proti takým názorom ostro vymedzujú. Cowie sa domnieva, že „metaetici zvyčajne rozvíjajú a hodnotia svoje teórie - čiastočne - na základe súladu týchto teórií 
s „bežným“ normatívnym úsudkom prvého poriadku. V tomto zmysle sú „metodologicky konzervatívni“““ (Cowie, 2015: 605). Ako uvidíme, tento vymedzjúci postoj nie je ojedinelý.

Známa Humeova námietka tvrdí, že z roviny sein nie je možné odvodit' rovinu sollen. Jestvujú pokusy falzifikovat' predmetnú námietku, ako sa o to pokúsil Max Black. Preto ponúka kontrapríklad na zamyslenie: „Fischer chce dat' mat Botvinnikovi. Jediný spôsob, ako dat' mat Botvinnikovi, je Fischerov t'ah dámou. Preto by mal Fischer t'ahat' dámou“" (Black, 1970: 27). Blackov protiargument by mal spočívat' $\mathrm{v}$ tom, že preskriptívny záver vyplýva z dvoch deskriptívnych premís. Niektorí filozofi, ako napr. Mandzela, nepokladajú jeho argument za dostatočný. Jeho návrh je iný: aby filozofi, ktorí pracujú v metaetike, „neredukovali význam morálnych súdov na čisto nedeskriptívny (preskriptívny, emotívny prípadne iný) význam a keby namiesto skúmania skutočného jazyka morálky neodvodzovali svoj ortiel' zo skúmania jazyka prispôsobeného svojim alternatívnym teóriám etiky (napr. emotivizmus)“" (Mandzela, 2008: 713). V takom prípade nebudú metaetické skúmania produkovat' výsledky, ktoré sú voči etike deštruktívne. Súhlasíme s jeho názorom, podl'a ktorého význam metaetiky pre etiku spočíva v tom, že človek je nútený klást' si otázky, predovšetkým odôvodnenia plnenia etických povinností, najmä v absolútnom zmysle, inak je len t’ažké ubránit' sa pokušeniu totalitných ideológií (Valco et al., 2019; Petkovsek, 2019). Podla Mandzelu by analýza oprávnenia takého plnenia $\mathrm{v}$ absolútnom zmysle mohla zabránit' zneužitiu pojmu morálna povinnost'.

Mikušiak, ktorý kriticky reaguje na Mandzelovo konštatovanie neoprávneného redukovania jazyka etiky na preskriptívnu rovinu. Kým Mandzela sa usiluje obhájit' poznávací nárok etiky, Mikušiak sa na problém pozerá z iného uhla pohladu. Mandzela v Mikušiakovej interpretácii tvrdí, že ,upriet' morálnym súdom kognitívny význam v tomto kontexte znamená upriet' im zmysluplnost““ (Mikušiak, 2017: 320), no podl'a neho je to zúženie pojmu zmysluplnost'. Zmysluplný rečový akt etiky môže byt' funkčný aj bez pravdivostnej hodnoty, napr. pokial' je zrozumitel'ný na báze známej z pragmatiky. Mikušiak uvádza prehovor „maj sa dobre“, ktorý nie je v skutočnosti rozkazom. Morálne súdy podl'a neho nemožno vnímat' ako hypotetické imperatívy. Uvádza príklad, podl'a ktorého hypotetickým imperatívom nemusí byt' morálnym súdom, ako potreba dostatku spánku, ak sa chceme mat' dobre. V každom prípade Mikušiakov implement k Mandzelovej obhajobe poznávacieho nároku etiky nenahráva deštrukčnému vplyvu metaetiku na etiku, skôr naopak.

Husserl sa na adresu pozitivizmu vyjadril, že stína fillozofii hlavu. Pozitivizmus mal nepochybne vplyv aj na vznik analytickej filozofie a tá priniesla okrem iného aj analytickú metafyziku. $\mathrm{Na}$ adresu metaetických skúmaní taktiež odzneli konštatovania, že znemožňujú etické súdy ako neopodstatnené. Nie je to pohl'ad väčšiny metaetických názorových pozícií a ani diskusia na stránkach Filozofie sa nepriklonila k takému názoru.

V mnohých prípadoch sa prejavujú prepojenia medzi problémami metaetiky a aplikovanej etiky, resp. potreba ukotvenia stanoviska v súdoch aplikovanej etiky nielen v etike, ale aj v metaetike. Vyššie uvádzame odporúčania Hareho v oblasti etického rozhodovania. Etické rozhodovanie patrí medzi základné problémy aplikovanej etiky. Domnievame sa, že v tejto oblasti častokrát nestačí sledovanie common sense, ale je potrebné určité metaetické ukotvenie.

Autorka Horná rozoberá vzt’ahy aplikovanej etiky ekonomickej proveniencie a filozofickej etiky. V rámci etických stanovísk spomína utilitarizmus, Kantovu deontologickú etiku, etiku cnosti Macintyra. Upozorňuje na uplatnenie teórie spoločenskej zmluvy v aplikovanej podnikatel'skej etike. „Firmám je umožnené podnikat' vd'aka presvedčeniu, že z podnikania bude mat' nepriamy úžitok aj spoločnost' a firmy majú určité povinnosti prezentovat' záujmy spoločnosti“ (Horná, 2018: 6). Spoločnost' zasa podporuje podnikanie cez podporu pozitívneho 
podnikatel'ského prostredia, alebo pomocou represívnych legislatívnych opatrení. V rámci filozofickej etiky sa Horná vyjadruje aj k situačnej etike, ktorej zakladatel’om je Fletcher. Základom je model konania v prospech agapé. Horná vníma situačnú etiku ako doplnkovú v zmysle využitia v podnikatel'skej etike, a to v prípadoch, pokial' štandardné modely zlyhávajú. Horná uvádza deontologický etický prístup, podl'a ktorého by sme nemali klamat' ani potenciálnemu vrahovi, pokial' by pravdivá odpoved' spôsobila potenciálnu násilnú smrt' človeka. Klamstvo je naopak podl'a situačnej etiky dovolené v zmysle vyššieho ciel’a zabránenia potenciálnemu zločinu.

Význam metaetiky v podnikatel'skej a manažérskej etike autorka Horná však napriek predstaveniu konkrétnych metaetických teórií rozvádza len $\mathrm{v}$ minimálnej miere. Domnieva sa, že je možné pozorovat' zdvihnutie životnej úrovne v rámci národa, čomu je podl'a autorky možné vd’ačit' vplyvu etiky a morálky na rozhodnutia, ktoré sú klúčové. Horná síce tvrdí, že ,,,dobré“ správanie splńa štandardy správania a prispieva k ciel'om, ktoré sú všeobecne považované za pozitívne“ (Horná, 2018: 7), ale význam a chápanie tohto pojmu v metaetickom zmysle nerozpisuje. Otázka samozrejme súvisí aj s „kultúrnymi prvkami bežnými v l’udskej komunite, ktoré ul’ahčujú globálne podnikanie a umožňujú dnešný globálny ekonomický úspech“ (Hart, 2009: 49). Túto otázku do značnej miery st’ažujú relativistické pozície, ktoré spochybňujú možnost' niečo považovat' za dobré vo všeobecnosti, a ktoré v dnešnej dobe prestávajú byt' celkom okrajovou záležitost'ou (Polacko 2018).

Pre praktikov v etike je dôležitá otázka, či veria v prírodnú, naturálnu podstatu etických vyhlásení, myslí si Davis (Davis, 2008: 162). V etike reklamy môže hrat' rolu, aká je podstata reklamy, či reklamu vnímajú aplikovaní etici ako prirodzenú, alebo ako nástroj vytvorený umelo. Z niektorých uhlov pohl'adu sa nám môže zdat' aplikovaná etika antirealistickou. Rovnako pokladáme za dôležitú otázku, či praktické etické teórie môžu byt' kompatibilné so slabou kognitívnou (nenaturalistickou) metaetikou, ako aj, či sú praktici schopní tvorit' asertibilné morálne vyhlásenia. Praktickým impaktom aplikovanej etiky môže byt' vykonanie dôkazu, že „že argumenty, ktorých ciel'om je preukázat' irelevantnost' etiky pri podnikaní, sú neudržatel'né“ (Mabaquiao, 2007: 14). Príkladom antirealistického a slabo kognitívneho pohl'adu môže byt' Turner (Turner, 1994). Pýta sa, či je pojem bezprávia, nespravodlivosti morálnej povahy. Ďalšou významnou otázkou je, či využíva teória praxe pojmy a fakty mimo teórie praxe na identifikáciu skutočných praktík? (Davis, 2008: 166). Je to podobné ako používanie definície pojmu humoru v praxi rozprávania vtipov a humorných anekdot, myslí si Davis. Pokial' budeme charakterizovat' praktickú aplikovanú etiku pomocou pojmov sociálnej istoty, budeme v podobnej situácii. Predpokladáme teda, že ukotvenie praktickej aplikovanej etiky by nemalo íst' mimo etických teórií.

„Ak máme nejakým spôsobom čelit' reálnej hrozbe nihilizmu a hodnotového relativizmu, ktoré drvia dušu dnešného človeka a v prospech ktorých navyše jestvuje mnoho dobrých argumentov, jediné, čo nám zostáva, je opätovne premysliet' základné l'udské skúsenosti, ktoré sú $\mathrm{v}$ rámci všeobecného kultúrneho sprostredkovania tabuizované alebo celkom ignorované, a poukázat' na ich pozitívne črty“ (Sucharek, 2017: 427). Problém hodnôt a možností ich použitia v aplikovanej etike je tiež dôležitý. Ich možné ukotvenie cez rôzne smery môže mat' rozličné podoby, na čo má vplyv aj to, podl'a akej metaetickej pozície postulujeme konkrétne hodnoty. Starostlivost' o zamestnancov je založená na určitých hierarchizovaných hodnotách, l'udská hodnota zamestnanca, ekonomické hodnoty v podniku. Vypracovanie etického kódexu možno sotva oddelit' od axiologickej problematiky, riešenie ekonomicko etickej dilemy môže niekedy byt' dané pod kuratelu etického kódexu, ktorý musí mat' určité ukotvenie $\mathrm{v}$ hodnotách. Tieto plne závisia nielen od filozofickej etiky, ale mnoho môže závisiet' aj od metaetického stanoviska spolutvorcov kódexu. Hodnoty 
môžu byt' vnímané cez intuíciu, alebo emocionálne, prípadne sa môže argumentácia opierat' o pozície etiky dobrých dôvodov, kde dobrým dôvodom nemusí byt' nutne hodnota. V ekoetike môžeme intuitívne ponímat' životné prostredie ako významnú hodnotu, deontologická pozícia zasa ukladá povinnost' chránit' životné prostredie, emocionalistická pozícia je o pocite, ktorý vedie k chráneniu prostredia, preskriptivistické stanovisko je zasa kombináciou intuície a kritického myslenia, vyplývajúceho napr. z enviromentálnych analýz. Tie môžu mat' impakt smerom k ekonomickým nástrojom, ako napr. enviromentálne dane, čo je priame prepojenie medzi ekoetikou e ekonomikou (Csikosova, Culkova, Mokrisova, 2015). V tejto súvislosti možno podotknút' zaujímavé zistenie, že enviromentálne faktory sú relatívne malé v oblasti vplyvu na kvalitu života (Zub, 2019: 83).

Metaetické ukazovatele a ich ovládanie je potrebné aj pre filozofických poradcov. Horák vo svojej monografii z nášho pohl’adu neoprávnene redukuje filozofické poradenstvo na etické poradenstvo (Horak, 2016). Aj ked' nesúhlasíme so závermi Horákovej monografie, domnievame sa, že bravúrna orientácia filozofa profesionála, ktorý vykonáva prax filozofického poradenstva v metaetických otázkach je conditio sine qua non, ked’že etická oblast' filozofických problémov tvorí jej významnú súčast'.

\section{Záver}

Prienik metaetiky a aplikovanej etiky ekonomickej proveniencie je oblast'ou, ktorej sa venuje málo pozornosti. Tomuto aspektu etiky sme sa venovali v našej štúdii. Zmapovali sme bibliografickú základňu v Čechách a na Slovensku, ktorá sa venuje tematike. Po stručnom historickom exkurze sme sa venovali metaetickým pozíciám. Pokúšame sa poukázat' na súvislosti medzi metaetickou a filozofickou pozíciou u Kierkegaarda. Kladieme si prvú otázku, či má význam hl'adat' prepojenie medzi filozofickou a aplikovanou etikou. Pokúšame sa o polemiku s Rortym, ktorý má na otázku záporný názor. Obhajujeme stanovisko, že medzi filozofickou a aplikovanou etikou jestvuje priame prepojenie. Postulujeme aj podobnú otázku, či jestvuje nejaké zmysluplné prepojenie medzi metaetikou a aplikovanou etikou orientovanou ekonomicky (manažérska etika, podnikatel'ská etika). Naša odpoved' je kladná. Argumentujeme určitou izomorfiou medzi procesom rozhodovania voblasti aplikovanej etiky podl'a uznávaných odborníkov a procesom etického súdu v etickej dileme u Hareho. Taktiež sa zaoberáme názorom, že niektoré metaetické pozície hovoria o etických úsudkoch ako o logickej chybe, čo v plnom rozsahu odmietame. Uvádzame viacero príkladov na ovplyvňovanie modelov správania $\mathrm{v}$ aplikovanej etike cez rozličné metaetické pozície, ako napr. v oblasti starostlivosti o zamestnancov, kreovania etických kódexov, ekoetických aspektov aplikovanej etiky etc.

Článok bol podporený interným grantom IG-KSV-ET-02/2016-2.1.5.

\section{Bibliographic references}

ABEL, F. 2007. The objectivity of theological meta-ethical foundation of human morality. In: Studia Theologica, vol. 9, n. 3, pp. 17-30, ISSN 1212-8570

AGUAS, J. 2006. Religious pluralism and freedom of religion. In: Journal of Dharma, vol. 31, n. 1, pp. 67-80, ISSN 0253-7222

ALEXANDER, R. E. 1974. Metaethics and value neutrality in science. In: Philosophical Studies, vol. 25, n. 6, pp. 391-401, ISSN 0031-8116

BILA, M. - KACMAROVA, A. - VANKOVA, I. 2015. Adopting cross-disciplinary perspectives in constructing a multiligual's identity. In: Human Affairs, vol. 25, n. 4, pp. 430 - 442, ISSN 1210-3055

BILA, M. - KACMAROVA, A. - VANKOVA, I. 2016. What is behind the compiling of a dictionary for a bilingual user? In: Evolving Nature of the English 
Language: Studies in Theoretical and Applied Linguistic 4, Bern: Peter Lang. pp. 201 - 209, ISBN 978-3631676257

BLACK, MAX. 1970. Margins of precisions: Essay in logic and language. NCROL BRAZDA, R. 2010. Ethicum. Praha: Verbum Publishing. ISBN 978-80-904273-9-6 COWIE, C. 2015. Conservatism in Metaethics: A Case Study, In: Metaphilosophy, vol. 46, n. (4-5), pp. 605-619, ISSN 0026-1068

CSIKOSOVA, A. - CULKOVA, K. - MOKRISOVA, V. 2015. Ecological elements implementation in the tax systém. In: Actual Problems in Economics, Vol. 164, n. 2, pp. 253 - 261. ISSN 1993-6788

DAVIS, J. K. 2008. What kind of metaethics does practice theory imply?, In: Soundings, vol. 90, n. 3-4, pp. 161-167, ISSN 0038-1861

DELAYCO, M. L. C. - BIANA, H. T. 2015. Dine in or out: Understanding the budgeting and eating out behavior of De la Salle University. In: DSLU Business and Economics Review, vol. 24, n. 2, pp. 136-149, ISSN 0116-7111

DONELSON, R. 2017. Rorty's Promise in Metaethics. In: Contemporary Pragmatism, vol. 14, n. 3, pp. 292-306, ISSN 1572-3429

DUPKALA, R. 2009. Philosophizing in Slovakia: Reflections and contexts (on the receptivity of the philosophical thought in Slovakia. In: Filozofia, vol. 64, n. 6, pp. 552-559, ISSN 0046-385X

DYTRT, Z. 2006. Etika v podnikatelském prostředí. Praha: Grada. ISBN 80-2471589-9

HART, N. 2009. A common ethical foundation for globalization: Metaethics, normative ethics and applied ethics. In: Internation Journal of Interdisciplinary Social Sciences, vol. 3, n. 11, pp. 49-54, ISSN 1833-1882

HONGLADAROM, S. 2006. Ethics of bioinformatics: A convergence between bioethics and computer ethics. In: Asian Biotechnology and Development Review, vol. 9, n. 1, pp. 37-44, ISSN 0972-7566

HORAK, O. 2015. Filozofické poradenstvo / kritika. Olomouc: Univerzita Palackého. ISBN 978-80-87895-31-3

HORNA, T. 2018. Analytický pohl'ad na vývoj etických teórií a stanovísk komponujúcich fundamentálnost etiky podnikania. In: Journal of Global Science, vol. 3, n. 1, pp. 1-8, ISSN 2453-756X

HRIBEK, T. 2016. Do animals have consciousness? In: Filosoficky casopis, vol. 64, n. 1 , pp. 3 - 22, ISSN 0015-1831

JOAQUIN, J. J. 2013. Does logic rest on a metaphysical foundation. In: Philosophia (Philippines), vol. 14, n. 1, pp. 2244-1875

JOYCE, R. 2006. Metaethics and emotions research: A responze to prinz. In: Philosophical Explorations, vol. 9, n. 1, pp. 45-53, ISSN 1386-9795

KOLAR, P. - SVOBODA, V. 1997. Logika a etika. Úvod do metaetiky. Praha: Filosofia. ISBN 80-7007-100-1.

KRALIK, R. 2013. The Reception of Soren Kierkegaard in Czech Language Writings. In: Filosoficky casopis, vol. 61, n. 3, pp. 443-451. ISSN 0015-1831

KRALIK, R. - PAVLIKOVA, 2013. The reception of Kierkegaard's work in Slovakia, In: Filozofia, vol. 68, n. 1, pp. 82-86, ISSN 0046-385X

LUKNIC, A. 1994. Štvrtý rozmer podnikania - etika. Bratislava: Slovak Academic Press. ISSN 80-85665-30-1

MABAQUIAO, N. M. 2007. The place of ethics in business, In: Philosophia (Philippines) vol. 41, n. 1, pp. 14-26, ISSN 2244-1875

MABAQUIAO, N. M. 2012. Ethics of business ads directed at children, In: Philosophia (Philippines) vol. 41 n. 1, pp. 46-58, ISSN 2244-1875

MAHRIK, T. 2017. Kierkegaardian pointers to metaethics. In: European Journal of Science and Theology, vol. 13, n. 5, pp. 119-130, ISSN 1841-0464 
MAHRIK, T. 2018. The golden rule of morality - An ethical paradox. In: Ethics and Bioethics (in Central Europe), vol. 8, n. (1-2), pp. 5-13, ISSN 1338-5615

MAHRIK, T. - KRALIK, R. - TAVILLA, I. 2018. Ethics in the light of subjectivity Kierkegaard and Levinas. In: Astra Salvensis, vol. 6, pp. 488-500, ISSN 2393-4727

MAHRIK, T. 2018. Metaetika. Bratislava: Porta Libri. ISBN 978-80-8156-142-9.

MAHRIK, T. - VASBIEVA, D. - KRALIK, R - KONDRLA, P. 2020. Salvation as the teleological vector in Kierkegaard's practice in Christianity, In: European Journal of Science and Theology, vol.16, n. .4, pp.43-52. ISSN 1841-0464.

MANDZELA, M. 2004. Facts, values and ethics. In: Filozofia, Vol. 59, n. 9, pp. 654 -664, ISSN 0046-385X

MANDZELA, M. 2008. Is ethics a consequence of logical error?. In: Filozofia, Vol. 63, n. 8, pp. $704-714$, ISSN 0046-385X

MIKUSIAK, M. 2017. Language and the method of metaphilosophy, In: Filozofia, vol. 72, n. 4, pp. 312-324

NAVRATILOVA, D. 2006. The status of ethics as a humanistic discipline within the context of technology civilisation. In: Filozofia, Vol. 61, n. 7, pp. $547-561$, ISSN 0046-385X

ONDREJKOVA, A. 2000. Etika a metaetika. Zvolen: Bratia Sabovci. ISBN 8089029-06-X

ORSZAGH, L. 2019. Pierce's understanding of abduction from the methodologicoeúistemological stadpoint. In: Filosoficky casopis, Vol. 67, n. 1, pp. 45 - 68, ISSN 0015-1831

PACOVSKA, K. 2006. Kritika metaetiky v díle P. Footové a dalších deskriptivistů. In: Studia Neoaristotelica, vol. 3, n. 1, pp. 62-74, ISSN 1214-8407.

PAVLIKOVA, M. - ZALEC, B. 2019. Struggle for the human self and authenticity: Kierkegaard's critique of the public, establisher order, media, and false christianity. In: Bogoslovni vestnik, vol. 79, n. 4, pp. 1015-1026, ISSN 0006-5722

PETKOVSEK, R. 2019. Theology Facing the Challenges of the Modern Anthropological Crisis: Preamble of the Apostolic Constitution Veritatis Gaudium. In: Bogoslovni Vestnik, vol. 79, n. 1, pp. 17-31. ISSN 1581-2987.

POLACKO, J. 2018: Relativism and the Meaning of a Game without Rules. In: BOCHIN, M. (Ed.): Quality of Life IX. Social and Ethical Dimensions. Mainz: Logophon Verlag GmbH. pp. 92-95. ISBN 978-3-936172-55-3

POLACKO, J. 2019: Christian culture as antagonism of relativism and byzantine singularity. In: PRIBISOVA, E. - POLACKO, J. (Eds.): New Dimensions in the Quality of Life. Interdisciplinary research. Mobile: York University. pp. 129-140. ISBN 978-0-8353-5031-X

REMISOVA, A. 2000. Etika a ekonomika. Bratislava: Ekonóm. ISBN 80-225-1259-1 REMISOVA, A. 2003a. Early Wittgenstein's on ethics. In: Filozofia, vol. 58, n. 3, pp. 169 - 170. ISSN 0046-385X

REMISOVA, A. 2003b. Wittgenstein's views of ethics in the middle and the late periods of his philosophical development. In: Filozofia, vol. 58, n. 7, pp. 437-449. ISSN 0046-385X

ROLNY, I. - LACINA, L. 2004. Globalizace, etika, ekonomika. Věrovany: Jan Piszkiewicz. ISBN 80-8676-804-X

RORTY, R. 2006. Is philosophy relevant to applied ethics? In: Business Ethics Quarterly, vol. 16, n. 3, pp. 369-380, ISSN 1052-150X

RUSNAK, P. 2018. Specific features of Florenski's personalism (the concept of the symbol as a unique relationship of language and personal being in Slavic thought). In: Konstantinove Listy, vol. 11, n. 2, pp. 168-178, ISSN 1337-8740

SMREKOVA, D. 2004. Does it make between ethics and morality?. In: Filozofia, Vol. 59, n. 8, pp. 549-562, ISSN 0046-385X 
STOROSKA, M. 2018. The book of Genezis as foundation for the european civilisation's concept of social help. In: European Journal of Science and Theology, Vol. 14, n. 1, pp. 61-74, ISSN 1841-0464

SUCHAREK, P. 2014. Self-Awareness and openness: Reconstruction of phenomenological approach in in psychotherapy. In: Filozofia, vol. 69, n. 10, pp. 847 - 858, ISSN 0046-385X

SUCHAREK, P. 2017. Reconciliation is not Forgiveness. Praise of Forgiveness. In: Filozofia, vol. 72, n. 6, pp. 417-428, ISSN ISSN 0046-385X

TAVILLA, I. 2018. 'ordet' by Carl Theodor Dreyer a Kierkegaardian movie?. In: European Journal of Science and Theology, vol. 14, n. 3, pp. 13-26, ISSN 1841-0464 TURNER, S. 1994. The Social Theory of Practices: Tradition, Tacit Knowledge, and Pressuppositions. Chicago: University of Chicago Press. ISBN 978-0226817385

VACEK, M. 2018. Fiction: Impossible!. In: Axiomathes, vol. 28, n. 2, pp. 247-252

VALCO, M. 2018. Global and local changes of the interaction of natural and human sciences. In: European Journal of Science and Theology, vol. 14, n. 5, pp. 1-3, ISSN 1841-0464

VALCO, M. - VALCOVA, K. - SLIVKA, D. - KRYUKOVA, N.I. - VASBIEVA, D. - KHAIRULLINA, E.R. 2019. Samuel Stefan Osusky's Theological-Prophetic Criticism of War and Totalitarianism. In: Bogoslovni Vestnik, vol. 79, n. 3, pp. 765785. ISSN 1581-2987.

VOLEK, P. 2015. Free will and neuroscience. In: European Journal of Science and Theology, vol. 11, n. 3, pp. 1-11, ISSN 1841-0464

WITTGENSTEIN, L. 1993. Tractatus logico - philosophicus. Praha: Oikoymenh. ISBN 80-85241-30-7

ZOUHAR, M. 2003. The reasons of the rise of analytical philosophy. In: Filozofia, vol. 58, n. 4, pp. 259-271, ISSN 0046-385X

ZOUHAR, M. 2004. Vznikla analytická filozofia?. In: Organon F, vol. 11, n. 2, pp. 202 - 207, ISSN 1335-0668

ZUB, O. 2019. Quality of human life as an indicator of the enviromental well-being, In: Perspectives, vol. 5, n. 1, pp. 83-93, ISSN 1339-8245

Words: 7734

Characters: 55990 (31,11 standard pages)

PhDr. Marián Ambrozy, PhD., MBA

College of International Business ISM Slovakia in Presov

Duchnovičovo námestie 1

Prešov 080 01,

Slovensko

ambrozy@imspo.sk 